\title{
A CONSERVATION PROJECT ON BIG GULLY CREEK
}

\section{by Christine Pike, Waseca}

Perhaps the Indian people had a name for it, but the white man came to call the long valley 'Big Gully'. Rising in the Streamstown area of Alberta, the Big Gully Creek winds east in its ancient bed in the bottom of the valley to enter the North Saskatchewan River northeast of the Saskatchewan town of Maidstone.

The entire length of the creek offers much that is of interest, but it is the area around the mouth of the creek that local people are most anxious to protect. Here are steep wedges of hills, covered by birch, spruce, mountain alder, highbush cranberry, and aspen. On the southern uplands are the intriguing, seemingly misplaced, spruce s.wamps.

In the river, across from the creek mouth, lies Pine Island, site of five fur-trading posts built in the late 1700's. Stirring events occurred here in days gone by, and the Big Gully country has much colorful history and folklore.

Among the early white settlers in this locality were the Fosters of United Empire Loyalist descen't, who arrived in 1902. Frank Dryden Foster so loved the unique beauty of the mouth of the Gully that he requested to be buried there. His grave, on his own land, overlooks the river and the island. It was in 1926, with the late historian Campbell Innes, that Foster had explored the ruins of the trading posts on the island, which is now under government protection, and where, in 1966, some archaeological studies were made.

One of the spruce swamps is on Foster land and some members of the family try to protect it as Frank Dryden Foster did. They also leased the land immediately around the creek mouth from the Municipality owning it. In the early 1950's, local people tried to have this land set aside as a protected area. Unfortunately, their efforts were unsuccessful.
Big Gully was part of my childhood, and the childhood of many others. It was to me a supreme adventure to take the long, winding south-side trail through the sandhills to the mouth of the Gully. I remember well the excitement of that first glimpse of the spruce swamps; the waving grass on the then unfenced plateau, and, at last, spread out below us, the North Saskatchewan River with its fascinating islands!

After I grew up, I would take my nieces to camp there, sometimes making the 60-mile round trip with horses. Cool nights, the thin wail of the coyote, does with their fawns, an unseasonable blizzard, a transient antelope, carpets of violets - they all became a grand kaleidoscope of memories.

But, in 1967, the Fosters lost the lease to a newcomer to the district.

On the long May weekend of 1970 , we followed the winding old wagon trail, and again saw the tops of the swamp spruce peeking over the hills. We again saw the long rolling stretch of open country that made you feel as though, just maybe, a buffalo could still be over the next rise. Yes, it was all still there. We set up our usual careful little camp, feeling ourselves a part of the past. That feeling was

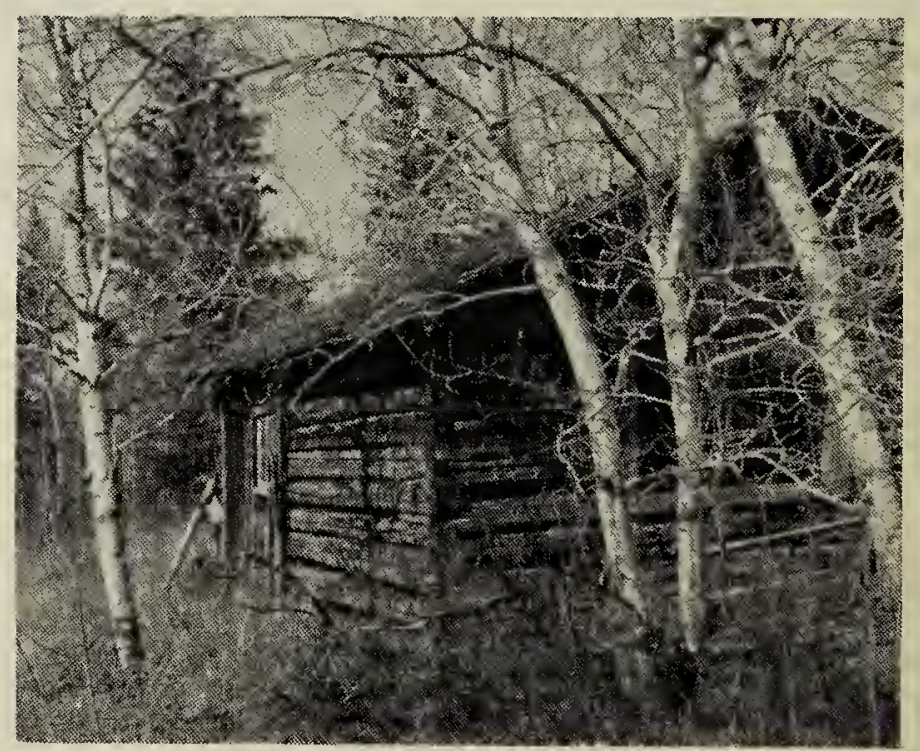

The first cabin built at the swamps by Frank Dryden Foster. 
short-lived. Next morning one of the girls walked down to the creek on a path that winds through spruce, came back and said, "There's been a bulldozer down there."

There had indeed. My unspoken foreboding had been justified. For about one-quarter of a mile on the sandy creek banks, a broad strip of spruce, birch, aspen and cranberry trees had been destroyed. The machine had been used to shove up, not one, but two temporary crossings, which naturally had washed out. An aimless track of destruction went up the old Indian Crossing trail. A grove of water birch had been smashed, and, if not for a "drift fence", the bulldozer would have gone right through where we were now camped, and down the peaceful path through the spruce. It all seemed so devoid of reason. Next day, across the creek, we saw more damage. We met the local Scout leaders there and they expressed the same dismay.

I had contacted the Natural History Society, on whose behalf Dr. Stuart Houston came on May 24th to visit Big Gully. He offered the Society's help in purchasing the land at the mouth of the creek so that it could be protected as a natural area. Dr. Stan Rowe and his biologists from the Saskatoon campus studied the area in June, in connection with the survey of Natural Areas for the International Biological Program.

Local people were contacted, letters written and 'phone calls made. Our M.L.A., the members of our local municipal council, the Wildlife Federation, the Maidstone Riding Club, a women's club, farmers, teachers and students were interested. The North Battleford radio station gave us excellent publicity, while the weekly Maidstone newspaper printed letters and articles.

Jim Wedgwood and Dr. Houston, along with a Maidstone high school teacher, the reeve of our Municipality, and myself, attended a council meeting of the Municipality owning the land. Though they gave us an attentive hearing and assured us the damage to the land had taken place without their per-

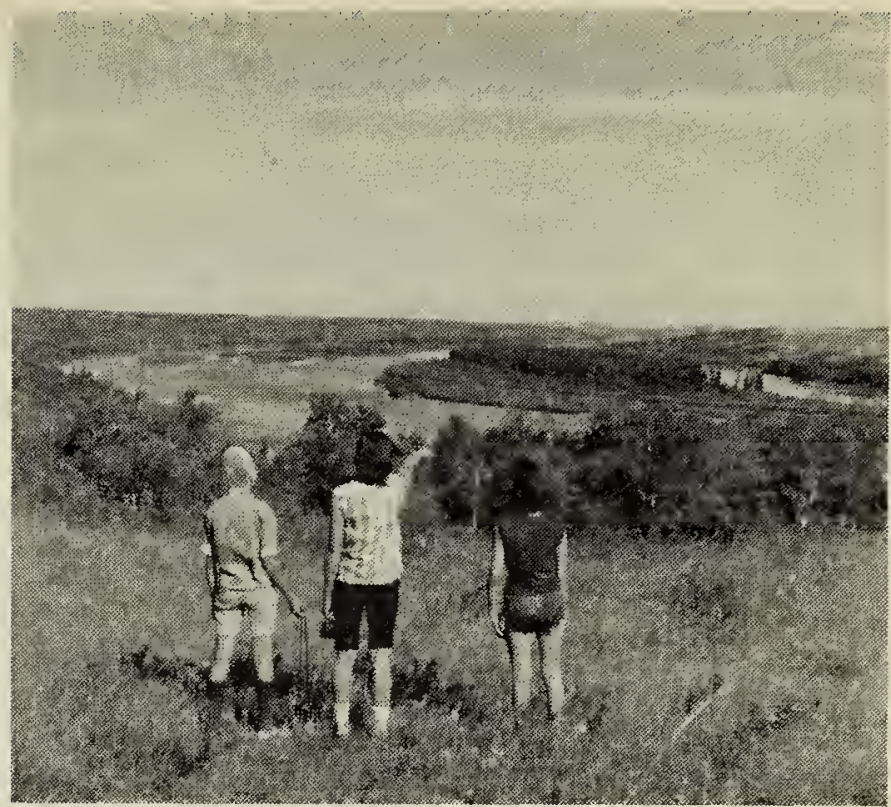

North Saskatchewan River and Pine Island.

mission, they did not wish to sell the land at that time. In May 1971, the 600 acres was put up for tender. We made an offer on behalf of the Natural History Society and obtained the lease for $\$ 390.00$ per year, for a three-year period. Local people proved their interest by donating enough money for this purpose.

Even if the financial support is given to renew the lease in the years to come, various factors indicate that constant vigilance is necessary. Our own area is not without its miridless element. Also, oil wells could be placed on the property, ending the tranquility, further obliterating traces of our storied past, and destroying any hope of a wildlife sanctuary.

We still have hopes that the government will see fit to preserve the area. At an August, 1971, meeting of the N.D.P. party in Cutknife constituency, a high school student moved a resolution that the land at the mouth of Big Gully Creek be protected. This motion carried and the local M.L.A. once more promised to help all he could.

How sad it would be if all our efforts, which are touched on only very briefly here, should end in failure. It seems that almost every month another beautiful place disappears, or a pioneer trail is plowed under, never to be replaced, never again to provide an experience for the eye, the mind and the heart. 